\title{
12 \\ Coming to terms with the state
}

Jim Jose

\section{Introduction}

It is an honour to be asked to contribute to this festschrift for Professor John Wanna. His distinguished career spans almost 40 years and I am pleased to be able to say that I was there more or less at the beginning, circa 1981, when John and I met as postgraduate students at the University of Adelaide and became firm friends. Since that time, John has produced an enormous body of work that has contributed greatly to our understanding of Australian politics and public policy. He has nurtured and mentored many young scholars launching them into careers of their own. By any measure his contributions to the study of public policy and the profession of political science have been substantial. The diversity of his work, and its depth, is such that I find myself somewhat daunted by the prospect of saying something beyond the obvious about its significance.

Reflecting on the trajectory of John's research publications I noticed something that seemed a little unexpected. Discussion of the state more or less disappears. In 1981, in Defence not Defiance, an important early monograph, the state occupies a central conceptual, explanatory and instrumental place. By 2016, in a collection of essays entitled Sharpening the Sword of State (Podger and Wanna 2016), there is no state to speak of. It has neither conceptual nor instrumental presence, despite what the title might be thought to imply. In that collection of essays, 
including John's co-authored piece (Allen and Wanna 2016), the state has a presence, certainly, but as a taken-for-granted term that can be deployed in an unproblematic way, as a background condition for the analysis of other phenomena. This is not to suggest that he was (or is) unaware or neglectful of its importance. Over the course of his career there were a few works (e.g. in 1986, 1988/1993, 1994 and 2006) where he explicitly discussed the state and considered it as a phenomenon in its own right rather than as something to be taken for granted in a merely instrumental way. Granted, Public Policy in Australia (1988/1993) is multi-authored and hence its discussion of the state might not be attributable solely to him, but it does not affect the argument I am advancing. These few papers notwithstanding, the state no longer held a key strategic place in his research. Instead, his research centred on a range of mechanisms and instruments of the various apparatuses of the state such as those concerned with budgeting and budget processes, the delivery of services, the executive and its role, and the like - a very different proposition.

This gave me pause for thought. Is this something that is simply peculiar to his research trajectory, a reflection of his particular choices along the way as to subject matter and research problematic? Or might it indicate something deeper going on, something about the nature of how we might research and understand politics and public policy in the twenty-first century? Since answering yes to the first question would make for a short and very uninteresting paper, I opted for the second question, especially as it offered an opportunity to reflect on the trajectory of efforts to theorise the state from the late 1970s into the first decades of the twenty-first century. Prompting that reflection is an underlying suspicion that the place of the state within John's scholarship mirrors a parallel decline in its prominence within public policy and public administration. Exploring that suspicion is the focus for this chapter.

Of course, one might object with the standard 'so what?' question. The suspicion might be misplaced because for much of the twentieth century the state, as an object of empirical and conceptual analysis, remained a non-issue within political science, internationally until the early 1970s (Almond 1988) and in Australia until the early 1980s (Galligan 1984, 82) - though possible exceptions might be Hancock (1930), Barraclough (1940), Mayer (1952) and Encel (1960). One might also object that the problem is really one of the appropriate level and field of analysis. At a macro level, especially for fields like comparative politics, international relations or political economy, the concept of the state 
remains central, a core unit of analysis with considerable analytic value. But at a micro level, where research and analysis explores the particulars of how the institutions and apparatuses of the state actually operate, the term loses its centrality as a unit of analysis. However, such objections mix up key questions about the nature of modern states with the minutiae of governing. They also obscure the possibility that there is something significant about its minimisation within public policy discourses. This is not to say that research on the state as such has been non-existent, since many scholars both within and on the boundaries of public policy and public administration have attempted to take the measure of the contemporary state (see e.g. Jessop 2015, 2004; Bevir and Rhodes 2010; Bell and Hindmoor 2009; Lister and Marsh 2006; Weiss 2005; Crouch 2004; Pierre and Peters 2000; McEachern 1990).

Common to these and other discussions of the state is the central (though often unstated) problematic of explaining how the power of the state is organised and exercised in the service of policy development and implementation, and on whose behalf and in whose interests that power might be exercised. Attempts to answer those questions, whether directly or indirectly, constituted the brief efflorescence of arguments in the 1970s and early 1980s about the state, which in turn saw other concepts emerge that appear to have displaced a concern with the state as such. In what follows I will consider four such concepts: 'political regime', 'governmentality', 'new public management' and 'governance'. I will begin with a brief overview of the state of the state within political science research (broadly construed) to contextualise John's views on the state, which will be outlined in the second section. I will then discuss briefly each of these four terms before drawing these threads together in the concluding section.

\section{Political science/public administration and the state}

For much of the twentieth century most political scientists seemed agreed that conceptual questions about the nature of the state were largely settled. Within mainstream political science the state could be accounted for in terms of pluralist theory (i.e. as a neutral umpire mediating between contending interests) or elite theory (i.e. where elite groups competed for control of state institutions). Central to both these approaches was 
a view that there were two spheres of activity - a private sphere of civil society where individuals pursued their private (i.e. economic) interests, and a public sphere of state activity, the domain of institutional politics. The revival of Marxist theory in the late 1960s amid the revolutionary decolonisation processes and growing economic turmoil accompanying the end of the post-World War II long boom generated significant rethinking about how to theorise the state, or more specifically the capitalist state (e.g. Miliband 1969; Poulantzas and Miliband 1972; O’Connor 1973; Yaffe 1973; Offe and Ronge 1975; Poulantzas 1978; Holloway and Picciotto 1978; Frankel 1979; Nordlinger 1981; and Jessop 1982). The key issues centred mostly on how one should understand the nature and role of the state in managing a capitalist society, and in particular managing conflicting class relations and interests to ensure optimised conditions for profitability. Paralleling these debates were at least two other threads also worth noting.

One of these threads was similarly a response to the economic crises of the 1970s. A number of political scientists began arguing that modern society was becoming ungovernable because government was overloaded with contradictory demands, especially from citizens demanding a greater say in how their governments exercised their authority (e.g. Crozier, Huntington and Watanuki 1975; King 1975, 1978; Rose 1975). These ideas provided the political framing for a suite of emerging economic ideas that eventually 'moved from the margins of influence to become conventional political wisdom with world-transforming effects' (Block and Somers 2016, 3-4; see also Blyth 2002; Bevir 2010; Jones 2014). This constellation of ideas is today more commonly referred to as 'neoliberalism' (Harvey 2007). This worldview became not just 'conventional political wisdom', but the common sense of our time (Jose 2003).

The other thread to note is more to do with the impact of the Marxist debates about the state on the then prevailing pluralist and elite theories of the state. Given the Marxist critiques noted above and the steadily growing empirical evidence pointing to the untenability of key assumptions of the pluralist paradigm, a number of mainstream political scientists rethought the weaknesses of pluralist and elitist approaches to theorising the state (e.g. Lindblom 1977; Dahl 1982, 1985). Interestingly, the impact and influence of Marxist scholarship on the state on emerging neopluralist scholarship on power and the state appears not to have registered in mainstream US accounts of neopluralism (McFarland 2007). That observation notwithstanding, as if in response to this thread of scholarly 
debates, the US Social Science Research Council, through its Committee on States and Social Structures, underwrote a new research program under the theme of 'bringing the state back in' that produced a number of key works (e.g. Skocpol 1979; Evans, Rueschemeyer and Skocpol 1985). In the somewhat melodramatic view of one US political scientist, 'the concept of the state ... had risen from the grave to haunt us once again' (Easton 1981, 303).

But the state was not all that began to 'haunt' political science. The women's liberation movement of the late 1960s and early 1970s challenged all of the above approaches by asking 'was the state patriarchal?', or at least was the state a manifestation of masculinist interests and biases? Their answers to these questions entailed critical scrutiny of the institutions of law, the family, domestic labour, paid work, politics and political power (see e.g. Firestone 1971; Gornick and Moran 1971; Millett 1971; Morgan 1970; Summers 1975). The so-called public/private dichotomy and its privileging of the idea of civil society was revealed as gendered: the idea of 'the private' involved not just the already acknowledged civil society activities of the market but the reality of the domestic spaces of interpersonal relations between women and men and children (Pateman 1983). With the exception of what became known as radical feminism (see e.g. MacKinnon 1982, 1983, 1989), most of these early critiques drew on one or another of the contesting political ideologies of the times (such as liberalism, socialism, Marxism, anarchism and so on).

The reverberations from all of these debates began to be reflected within Australian political science by the early 1980s (see e.g. Frankel 1983; Sawer 1983; Head 1984; Galligan 1984), notwithstanding the earlier consideration of Marxist debates by Barbalet (1974) and Frankel (1979). Various works of political economy (e.g. Connell 1977; Catley and McFarlane 1981; Crough and Wheelwright 1982; and Wheelwright and Buckley's five-volume edited collections of essays 1975-83) as well as those by Australian feminists (Sawer 1983, 1990; Game and Pringle 1983; O’Donnell 1984; Franzway, Court and Connell 1989; Watson 1990) all presupposed these international debates and contributed to a broader understanding of the Australian state. Finally, and in addition to the unfolding debates within Australian political science, two other interrelated dimensions contributed (and continue to contribute) to shaping these debates and ongoing ideas about the state. On the one hand there is the ever-changing dynamics of global market forces (conveniently but misleadingly described as 'globalisation'). On the other hand, and 
itself a response to these global dynamics, is the ongoing reorganisation of particular state functions, their institutional design and institutionalised practices. This is the background against which the decline in the use of the state as a key conceptual term within John's scholarship parallels its decline within public policy and public administration.

\section{Wanna and the state}

In his first monograph, Defence not Defiance (1981), Wanna understood the state as an entity encompassing:

the instruments of government: both policy-making bodies (cabinet, parliament and government departments), and the bureaucracy (public service and local councils). In addition, the state also includes the judiciary (the court system in each of its various branches; criminal, civil and industrial), and the legal structure, the agencies of social control (police, military and intelligence organisations), the public financial institutions and to a lesser extent the public statutory authorities. (Wanna 1981, 42)

Variations on this summary were also sketched in both editions of Public Policy in Australia, though these also expanded the scope of 'the institutions of the state' to include entities one might ordinarily have thought should be excluded such as the church, political parties, pressure groups and trades unions (Davis et al. 1993, 24). These were the means to create, implement and enforce whatever policies might be needed to maintain and reproduce the state's particular social order, and in particular to resolve whatever conflicts might arise between various competing social, economic and political interests. The state remains obligated to upholding the social order in which it is embedded, while managing whatever degrees of social change might be needed.

Unsurprisingly, as Wanna subsequently pointed out, no matter what action the state takes it 'continually exerts significant influence over the economy and patterns of economic activity' (Wanna 1994, 227). However, for Wanna, this did not really amount to the state having control over the economy, since on his analysis in 1994, 'the management of the macroeconomy seems generally beyond state capacities' (Wanna 1994, 243). He suggested a number of reasons for this but chief among them were, on the one hand, the international global dynamics that shape and impact the domestic economy, and on the other, that the private sector 
'serves as the reciprocal dimension of state capacities' (Wanna 1994, 243) insofar as it exercises considerable control of key economic resources. This is further reinforced by the fact that there is more or less agreement on the fundamental values of the political-economic order such as the sanctity of private property, a significant degree of corporate autonomy, a minimalist approach to the redistribution of wealth and the subordination of the demands of labour to those consistent with business profitability (Lindblom 1977, 233, 205).

Nonetheless, Wanna was not suggesting that the state remains powerless, or that the ongoing processes of globalisation have necessarily weakened the state's ability to act, though it has 'transformed the means through which the state seeks to influence outcomes' (Mintrom and Wanna 2006, 162; see also Keating 2004). To the extent that the state is responsible for maintaining and reproducing the social order it also has to take policy positions that at any given time will favour some interests at the expense of others. Far from being a means to resolve conflict this is often a source of conflict on a number of levels: between the state and various interest groups, within the state and its various instruments of government concerning the strategies and policies to be developed and pursued, and between the political parties vying to represent the interests of their supporters. As Wanna $(1981,1994)$ has variously pointed out, the state is not neutral in the adjudication of such conflicts. The dominant influence of the fundamental values noted above ensures that the state cannot be neutral, especially as the state is the only entity with the authority and legitimacy to impose and enforce society-wide 'solutions'.

And so, it is fair to say that in Wanna's view the state is still a central actor, but how should one characterise that centrality? Should the state now be considered merely as a rule-setter, a guarantor of order, a facilitator, a coordinator, some sort of relay station, something else again or a combination of some or all of the above? How should we understand the diverse ways in which the state operates in terms of its administrative capacity and practices, its policymaking and delivery? Explanations attempting to take these issues into account have led away from a statebased language of analysis to other ways of conceptualising the state's activities and the various processes by and through which it has undergone various transformations. This is partly because the concept of the state, though important for the reasons already noted, operated at a fairly high level of abstraction. Its use seemed limited for explaining how its power might be manifested (and in particular how policies were developed and 
implemented), or how government and its agencies actually behaved. Yet even then its explanatory value might be considered questionable. The rest of the chapter will now consider some of these other ways of coming to terms with the state, of how we might understand the multiple, diverse activities of the state. What follows is not so much a history of these approaches as a series of snapshots summarising key aspects of their conceptualising and understanding of the machinations of the state and, by extension, the exercise of political rule.

\section{Political regime}

The first approach I would like to consider is the concept 'political regime'. Political scientists use this concept in a number of ways. The most common is to identify a particular coalition of political groups or individuals that exercises the prevailing sovereign power and accepts the rules legitimising and constraining that power. In this sense 'political regime' captures those empowered to rule. But this is a bit too limited, given that conceptually speaking, the idea of 'political regime' would seem to encompass more than just a means to describe who rules. Another quite common use of the idea of 'political regime' is as a means to classify different types of rule such as a democracy, or oligarchy, or monarchy, and so on. This second sense then aims to tell us something about the nature of political rule. It gives some idea of the organisational terrain, 'the locus of decisionmaking' to borrow Przeworski and Limongi’s $(1993,58)$ phrase, in which a given government is required to operate.

Yet despite this second approach covering more than those who rule, whether singly or as coalitions, it is more than the government of the day' (Pempel 1997, 338). It also involves the determinations about who gets what share of the difference between the total wealth generated and the cost of running the government, the 'fiscal residuum' as Przeworski and Limongi's $(1993,58)$ term it. Thus on this reckoning, the idea of 'political regime' fuses together an understanding of political institutions, aspects of the prevailing socio-economic order, and a specific mixture of public policies. Accordingly, this interpretation of 'political regime' allows the identification of a regularized pattern of political and economic interactions that are synergistic in character' such that all three aspects of the fusion noted above inform and reinforce one another (Pempel 1997, 338). Implicitly at least, this understanding of the idea of 'political regime' carries with it an alignment to a particular social order (Pempel 1997, 338). 
Yet even this conceptualisation omits dimensions that need to be included. Apart from diluting the class relations that might be of some significance for an understanding of how these three aspects actually interact, there is no reason to assume any definitive correlation between a given regime and any particular social order. To make that correlation, some sort of normative or value dimension must already be present within the concept of 'political regime'.

A different conception of 'political regime', developed from a neo-Marxist perspective, emerged in the late 1980s in the work of McEachern (1990, 13-41). His aim was to develop a conceptual approach that would make it possible to explain how and in what ways capitalist social relations and, by extension, the relations between classes, changed over time $(1990,41)$. This would then enable him to develop a way of understanding the nature and articulation of state power, class power and class interests so that it could be adequately theorised in terms of explaining specific policy outcomes developed by the state. Given that the state has the organisational power and social legitimacy, in theory at least, to act on and advance its own interests, McEachern $(1990,30)$ asked why the state has not made real its potential for 'full autonomy and social dominance'? The short answer is that while the potential for such an authoritarian outcome is always ever-present, in a healthy liberal democracy there are constitutional limits to guard against such unfettered autonomy on the part of the state. In most normal circumstances, and even in so-called states of emergency, a state is hard-pressed simply to impose its will come what may, provided that it maintains a reasonable level of 'performance legitimacy' by sustaining its citizens' faith in its institutions of government, including its bureaucracy and its capacity 'to initiate and implement the requested policies' (Andersen et al. 2014, 1308).

Even though it might be the case that a given state action or policy 'may bear the marks of the influence or initiative of one section of a class, its organisations or political party' it does not follow from this that we can read off 'the consequences of the policy, understood in terms of its impact on classes and class interests' (McEachern 1990, 32). There are no guarantees as to how the mix of powers, interests, ideas and political locations will play themselves out. Situating his account explicitly within the problematic of capitalist social relations, McEachern's notion of 'political regime' goes beyond the above two conceptions because it does not shy away from the class dynamics that shape and are shaped by the prevailing social order. 
Implicit in McEachern's notion of 'political regime' is a sense in which continuously contested guiding principles and norms are built into it. Both in principle and practice, McEachern's idea of 'political regime' has distinctly prescriptive dimensions. When talking about a political regime one is also talking about a particular alignment of class forces. Each conditions the other such that the shift from one political regime to another maps at the same time a reconfiguration of class forces and their political manifestations. Thus, McEachern's notion of a 'political regime' ensures that the analysis does not lose sight of the complex interplay of the social relations that give rise to the formation and shifts in political regimes (cf. Dean and Villadsen 2016, 20-21).

Yet despite the explanatory potential of McEachern's concept of 'political regime', its emphasis on class relations perhaps positioned it on the wrong side of history. For all its sophistication it seemed to leave hanging the key question of how the state's bureaucracy might be constituted in order to contribute to and implement any given policy. In some respects, the explicit class focus left considerations of the bureaucracy in much the same place as Miliband (1969) some 20 years earlier, and, in a slightly different way, Pusey (1991) a couple of years later. While I would argue that one cannot understand the nature of contemporary politics without some understanding of the prevailing class dynamics and hence McEachern's concept of 'political regime' retains some contemporary relevance, concern about the state qua state did not have much resonance at a time when the end of history had arrived and liberal democracy was being repositioned as the only game in town (cf. Fukuyama 1989). In that context, other ways of coming to terms with the state began to find favour.

\section{Governmentality}

A totally different approach to thinking about the state emerged from the work of French philosopher Michel Foucault and his concept of 'governmentality' (Foucault 1979, 1982). At a first approximation, it could be said that Foucault aimed to capture the specific understandings and practices of political rule adopted or developed by those empowered to govern. This oversimplifies the conceptual complexities involved in Foucault's research agenda, but it nevertheless provides an initial orientation for the concept. 
In Foucault's view, the then prevailing approaches to theorising the state drew on particular understandings of sovereignty shaped by strategic and/ or juridical conceptualisations of power, irrespective of the particular form of sovereignty, be it monarchical, republican or some other popular form (Foucault 2004). On these understandings power was a property to be possessed, to be struggled over, and so on, and conceived 'in terms of law, prohibition, liberty, and sovereignty', emanating from a singular centre (Foucault 1984, 90). What was needed was a different theory of power, one that was neither beholden to nor derived from whatever was theorised as the sovereign authority, one that could conceive of 'power without the king' (Foucault 1984, 91; see also Foucault 2004, 34-40). Rejecting this juridical and strategic approach, Foucault conceptualised power as being 'exercised from innumerable points, in the interplay of nonegalitarian and mobile relations' (Foucault 1984, 94). The locus of sovereignty came to be de-centred and de-individualised as the art of government came to embrace more and more domains previously subsumed under the pre-modern governmental model of the family (Foucault 1982, 1981).

Power relations could be creative, productive, repressive or destructive, or a contradictory admixture of all four. But significantly for Foucault (1979, 27), there could be 'no power relation without the correlative constitution of a field of knowledge, nor any knowledge that does not presuppose and constitute at the same time power relations'. Powerknowledge relationships were products of language and discourse, since these were the means by which power and knowledge relations became known, or at least theorised and understood. For Foucault, language is organised into specific discourses, which then created what he called disciplinary practices, understood in a double sense: (1) as a body of knowledge and (2) as a mode of practice situating and constituting humans as beings in the world. The disciplinary practices created through a particular discourse (or intersecting sets of discourses) also refracted back on to the discourse to help regulate it. Space precludes expanding these important aspects of Foucault's philosophy, but suffice it to say that he was concerned with the multiple ways in which language and discourse produced 'the different modes by which in our culture, human beings are made subjects', a process he termed 'subjectification' (Foucault 1982, 777). Through this process people are disciplined both as individual consciousnesses or agents and as members of a given social and political community (Foucault 1982, 777). The dynamic between discourse and 
discipline was at one and the same time the dynamic between knowledge and power and as such challenged the idea that our knowledge was either certain or grounded on incontestable foundations.

In developing his concept of governmentality, Foucault brought together four crucial dimensions: (1) the link between the idea of government and modes of political rationality; (2) the relationship between forms of power and processes of subjectification; (3) the complex ways in which technologies of self (ideas and practices through which individuals crafted their subjectivities) and technologies of domination (the ideas and practices through which governing powers enforced particular outcomes) were enmeshed in the workings of the modern state; and, finally, (4) the necessity of freedom for effective political rule. This provided Foucault with a way of conceptualising the art of governing in terms of 'guiding the possibility of conduct and putting in order the possible outcome' (Foucault 1982, 789), an art he termed the 'conduct of conduct' (Foucault 2008, 186). He regarded governmentality as a 'method of decipherment', meaning the means to uncover and analyse the specific and dominant rationalities of governing and the technologies or practices that enabled such rationalities to be made real, regardless of the scale involved (Foucault $2008,186)$. In short, governments govern by influencing the actions of others', though for Foucault it was governing in a very much broader sense than had come to be accepted by scholars in their analyses of government in the modern era (Foucault 1982, 790; 1997, 156). Such an approach enabled him to move beyond the abstract level of the state to call into question the commonly accepted understandings of the constitution and exercise of power (Foucault 2008, 2007, 2000, 1982), and to engage in the 'analysis of micro-powers' (Foucault 2008, 186).

Under the auspices of the concept of governmentality Foucault showed how the state was not the exclusive locus of sovereign power. Rather it was merely one, albeit a significant one, of any number of key actors in the multiple circuits of power that 'connect[ed] a diversity of authorities and forces, within a whole variety of complex assemblages' (Rose 1999, 5). Thus, not only did Foucault's governmentality approach decentre the reign of the autonomous individual, it also decentred the state as the locus of sovereign authority with respect to decision-making around policy matters. By decentring is meant the displacement of previously privileged concepts, ideas and practices as organising principles for how we interpret phenomena within our conceptual schemas. Governmentality proved to be very attractive to scholars aiming to understand the workings of public 
policy and public administration, because it shifted the focus away from 'linear and hierarchical perspective[s] which underl[y] much discussion about policy-making' (Colebatch 2002, 35-36; Dean and Hindess 1998).

Yet there is a tension in Foucault's approach, as is evident from his opening comment in his first lecture in The Birth of Biopolitics where he noted that 'the state is at once that which exists and that which does not yet exist enough' (Foucault 2008, 4). That is, governing presupposed 'a state which is already there', but the art of governing, governmentality, meant that the state was constantly being remade. It was but a short step from the idea of remaking the state to decentring the state. For many Foucauldians, and perhaps even for Foucault himself, the idea of decentring the state seemed to sit very easily within various anti-statist (i.e. anarchist or libertarian) perspectives, or what Dean and Villadsen (2016) aptly termed 'state phobia'. While governmentality provided a powerful means to explore the operations of the state, and to identify and analyse the arts of governing, it privileged an anti-statism that diminished attempts, including Foucault's own initial concerns, to understand how the state reproduced itself and its capacities.

Foucault's development of the idea of governmentality presupposed an understanding of governing that went beyond the normally accepted spheres of the political institutions of the state. But as noted above, this understanding of government also underscored forms of anti-statism that worked against positive conceptions of the state. It also saw many Foucauldians uncritically moving towards another conceptual shift that was on the rise at around the same time, and one that seemed to resonate favourably with Foucauldian perspectives. This was the idea of governance. Some have equated Foucault's 'conduct of conduct' with 'governance' (e.g. Sokhi-Bulley 2011, 252, fn 5; Singer and Weir 2006, 449) which in turn led some to treat 'governance' and 'governmentality' as interchangeable terms. But this move is a misreading of Foucault and the radical challenge his concept of governmentality posed (Jose 2010). Foucault's 'governmentality' aimed to displace past views of sovereignty and the state as central organising features of our understanding of political rule. To the extent that his idea of the 'conduct of conduct' could be described as 'governance' it bore little or no relation, either conceptually or politically, to the idea of governance that was gaining prominence as a key concept in the political science and public administration literature in the 1990s. Rather, the non-Foucauldian governance owed much to 
an already ascendant set of discourses characterised under the name new public management (NPM), and it is to those discourses we will turn to first, before considering 'governance'.

\section{New public management (NPM)}

New public management (NPM) was less a worked-out theory or cluster of theories about the state and more 'a conceptual device invented for purposes of structuring scholarly discussion of contemporary changes in the organization and management of executive government' (Barzelay $2005,16)$. Over time it became a series of measures developed and applied by governments to reorganise or modernise their public sectors (see e.g. Wilenski 1988; Aucoin 1990; Pollitt 1990; Hood 1991; Dunleavy and Hood 1994; Rhodes 1997 and this volume; Clarke and Clegg 1999; Dent, Chandler and Barry 2004; Torres 2004; Kirkpatrick, Ackroyd and Walker 2005; McLaughlin, Osborne and Ferlie 2005; Lynn Jr 2006; Pollitt, van Thiel and Homburg 2007). The roots of these measures reach back into the economic turmoil and political crises of the 1970s and the concomitant preoccupation with 'government overload' and the feared prospects of 'ungovernability', which in turn saw the post-World War II Keynesian consensus give way to a different constellation of ideas about the role of government and economic management, a consensus now commonly understood as neoliberalism (Skidelsky 2019; Block and Somers 2016; Jones 2014; Bevir 2010; Blyth 2002). Even if it is the case, as is argued by Shergold and Podger in Chapter 14 of this volume, that senior public servants in Australia did not speak about neoliberalism or use the term 'neoliberal' in their deliberations and discussions of policy (or research underpinning such discussions), it is still appropriate for scholars to describe as neoliberalism the dominant ideological and intellectual ideas that comprise the milieu within which such activities take place. Christensen and Laegreid $(2002,268)$ make a similar point with respect to practitioners' non-use of the term 'new public management' in the two decades prior to it being coined by Hood in 1991 .

NPM signifies a paradigm-like shift in thinking shaped by what Roberts (2010) has termed a 'logic of discipline' in which governments are seen as a significant part of the problem. This logic has two key prongs. The first is a recognition that conventional methods of democratic government and public administration have failed to deliver what is expected of them 
(cf. Rhodes this volume). The problem is sheeted home in governments' and politicians' inability to think outside their need for re-election and a propensity to make irresponsible decisions. Hence the rhetoric of reform emerges as a major discursive force to shape the thinking of practitioners and politicians alike. The second prong involves devising means or tactics to give effect to these reforms in ways that constrain the democratic impulse of politicians and voters on the one hand, and on the other, enable key decisions to be removed from the hurly-burly of everyday politics, a process of 'depoliticization' as Roberts terms it. In addition, he notes:

there are strong substantive commonalities in the way that reform is justified ... that sometimes go unrecognized by the stakeholders themselves, and certainly none would refer to a 'logic of discipline' itself. (Roberts 2010, 13-14)

The commonalities that Roberts had in mind were everyday tropes, like most politicians are ignorant of the realities of doing business, most politicians lack an understanding of basic economic dynamics, politicians are prone to pork-barrelling at the expense of the long-term health of the economy, politicians are poll-driven, and so on (I am sure readers can add more to the list). There were four interrelated propositions that provided the intellectual rationalisations for the application of the logic of discipline', which underwrote a reshaping of what Roberts termed 'the architecture of government'.

These four propositions were central to the international thinking around the development of NPM, at least within those circles in which the Keynesian consensus had given way to the dominance of monetarist-informed neoclassical economics (Buchanan and Wagner 1977; Skidelsky 2019) and a predominantly neoliberal form of politics. First, all alternatives to the market were deeply flawed. Market-based decisions were nearly always more reliable and effective than government planning. Second, government failure was more prevalent than market failure. Third, government-imposed regulatory frameworks were mostly counterproductive, that is, government intervention did not work. And fourth, government intervention was unjust as it usually resulted in the transfer of resources to the undeserving. In one way or another these propositions reflected the dominant input of public choice theory and private sector management theory that together with the above propositions might be 'best described as [a] "paradigm", because they 'combine both intellectual and ideological dimensions' (Aucoin 1990, 116). This does 
not deny that governments, in varying degrees, abandoned the need to address market failures or provide public goods and social protection. Governments were mindful, most of the time, of the social dimension and potential political fallout from their pursuit of particular policies. Social justice sentiments were not ruled out of considerations within the NPM paradigm, they just carried a different weighting in the political calculus.

Another defining characteristic of NPM was its focus on 'modernising' (i.e. reforming) the public sector. This was understood to mean remaking it in the image of the private sector by drawing on 'private sector-derived accounting and management technologies in the pursuit of public sector efficiency' (Lapsley 2009, 2). Across most of the Organisation for Economic Cooperation and Development (OECD) nations and beyond, government bureaucracies were transformed in varying degrees into market-oriented organisations that were to be competitive, performancefocused, cost-effective and audit-oriented (Bale and Dale 1988; Aucoin 1990; Hood 1991; Lynn Jr 2006), though in the UK context McLaughlin and Osborne $(2005,2)$ suggest that it was less about marketisation and more about the diversification of the 'unitary government provision and management of public services'. Nonetheless, the modernising dynamic of NPM and its accompanying rhetoric was both a rationale for and a consequence of governments' efforts to commercialise, corporatise or privatise a wide range of its activities. This also saw formal commitments to develop and implement competition policies such as occurred in Australia in 1994, which, among other provisions, introduced the principle of competitive neutrality to ensure that private sector companies and government-owned businesses and departments operated within the same commercial framework.

A third defining characteristic of NPM was the devolution of everyday levels of decision-making to lower echelons while effecting a greater level of centralisation (and political control) of the decision-making capacity of the senior executives of the bureaucracy (Aucoin 1990, 120-125). Despite their seemingly contradictory nature these dynamics very much reflected the influence of private sector management practices. It also reflected the view articulated forcefully by Osborne and Gaebler (1992) in their influential, though fanciful, book Reinventing Government that policymaking and its implementation are separate activities. Setting the policy agenda is what governments should do and implementing it should be left to market-sensitive entities, whether private or public. According to Osborne and Gaebler, echoing the views of Drucker (1968) from three 
decades earlier, governments are not good at rowing, hence they should steer and leave the rowing (i.e. the delivery of their services) to those with the requisite expertise and capacities. That their evidence for a lack of ability to row was more anecdotal assertion than demonstrable fact was neither here nor there.

Much more could be said about the minutiae of NPM, but it is clear from the above that NPM informed much of the thinking enabling the shift away from traditional public administration practices to allow public sector agencies and departments to become more like those operating in the private sector. Yet the outcomes have not turned out as intended insofar as the promised benefits have proved difficult to achieve (Lapsley 2009), despite there being some evidence of a positive impact in terms of assisting many state entities to improve their efficiency levels, to become more cost conscious and to become more creative or entrepreneurial in discharging their responsibilities (Diefenbach 2009, 896). On the other hand, the increased turn to auditing requirements, for example, has arguably resulted in increased costs, a preoccupation with compliance and a decline in attending to core activities (Lapsley 2009, 12-13).

Perhaps more worrying is the potential for governments (and the politicians who comprise them) to undermine their own legitimacy and that of the democratic state' (Lynn Jr 2006, 130) through a lack, or at least minimalist forms, of democratic accountability. And while it is the case that NPM emerged from deliberate choices undertaken by politicians and others within their respective nations, the long march of the NPM reforms and the changes they have put in place were not a result of the state and its agencies removing themselves from economic activity and the market. Rather it was a result of the state reconstructing the market regime and redefining its role within that regime. This is a point made in a slightly different context by Wanna when he and his co-author argued, perhaps echoing Keating (2004), that the "'nation-building" state has not disappeared but remains active in shaping and redirecting market mechanisms' (Mintrom and Wanna 2006).

Even so, for NPM it seems that its time has passed in terms of being 'the torch of leading-edge change', its embeddedness and institutionalisation notwithstanding (Dunleavy et al. 2006, 468). As a conceptual frame for interpreting the operations of the state then, NPM has lost its lustre. Its possibilities as a paradigm (Aucoin 1990) seem to have been exhausted as events have forced a rethink of its intellectual capacities and 
its particular practices - though this is not to deny its significant influence and part in helping redesign the architecture of government. Just what is lining up to take its place remains to be seen, though Dunleavy et al. were opting for what they called 'digital era governance', stressing that it was 'about governance, it is not solely or even primarily about digital changes' (Dunleavy et al. 2006, 469). This is because they see an increased role for the state, one that within an enhanced digital environment needs to be holistic and integrative. Similarly, Rhodes (this volume) sees variations on the networked governance theme as having moved beyond NPM, in particular what he terms 'decentred governance'. What can be noted here is that the concept of 'governance' emerged within the discursive formation of NPM and rapidly developed a key terminological place within it. It is to the concept of 'governance' to which I now turn.

\section{Governance}

The appeal of 'governance' as a term was that it seemed to provide a convenient means of settling conflicting debates over theorising the dynamics of the state and its institutions. In part, this was because it appeared to offer a way of examining and explaining the interrelated processes of government and governing without putting the state at the centre of the analyses. In that sense, it offered the capacity to decentre the state in much the same way as Foucault's governmental approach. But 'governance' offered other advantages. It was (and still is) a conceptually slippery term. It could circulate within and between disparate disciplines and fields of study with apparent ease, which allowed scholars to ascribe diverse and conflicting content and meanings to it. This was part of its appeal. Its conceptual slipperiness, even disciplinary promiscuity, meant that it could 'be applied to almost everything', though whether it 'describes and explains nothing' (Jessop 2003,4) is a matter of considerable debate (cf. Offe 2009). Nonetheless, the extent to which 'governance' remains a prominent term can be seen from the discussion offered by Rod Rhodes in Chapter 10 of this volume.

Stoker $(2019,13-14)$ suggests that governance, both as concept and practice, arose as a response to 'globalisation, [a] weakening of national sovereignty and the emergence of more challenging citizens'. But this ignores a number of things. First, responses to the 'emergence of more challenging citizens' had been unfolding since the mid-1970s (cf. Crozier, Huntingdon 
and Watanuki 1975; King 1975), and found concerted expression within various NPM strategies. Second, the challenges of globalisation and the concerns over national sovereignty were also unfolding long before the idea of 'governance' emerged. And this is the third point. 'Governance' as a term only came to prominence within political science discourse in the early 1990s (Jose 2007), partly as a result of its promotion by World Bank publications (1989, 1992), and partly by scholars reworking the discourses within and around NPM and public administration. This does not mean that the term had no currency prior to that time. It did, but it was mostly within a corporate management setting where the concern was about management structures and corporate accountability. And so it is not surprising that it enters contemporary political discourse via various World Bank publications (1989, 1992).

For it was the World Bank that provided a 'go to'(and seemingly innocent) definition of 'governance' as 'the manner in which power is exercised in the management of a country's economic and social resources for development' (World Bank 1992, 1). The political nature of that definition was revealed in a footnote in which the bank noted that its focus was with 'the processes by which authority is exercised in the management of a country's economic and social resources' and 'the capacity of governments to design, formulate, and implement policies, and, in general, to discharge government functions' (World Bank 1992, $58 \mathrm{n}$ 1). The nature or type of government was supposedly not its concern as it was 'outside the Bank's mandate' (World Bank 1992, 58, n 1). Notwithstanding its supposed apolitical positioning, the bank's core focus was with how governing was both organised and exercised, political in all but name. The World Bank's focus was similarly reflected in the works of many scholars who came to exercise significant influence in shaping contemporary understandings of governance (see e.g. Bevir and Rhodes 2003; Richards and Smith 2002; Hill and Hupe 2002; Lynn Jr, Heinrich and Hill 2000; Pierre and Peters 2000; Rhodes 1997; Stoker 1998; Kooiman 1993; McGregor Jr 1993; Wamsley 1990).

Over time, 'governance', like NPM, became more than just a concept. It generated a language of political discourse, at least within the fields of public policy and public administration, that formed its own paradigm for framing scholarly (and practitioner) understanding of contemporary modes of governing (Peters 2003; Stoker 1998). But 'governance' represented more than a shift in scholarly terminology; it also signified a technology of governing, a 'specific modality of 
government' (Prozorov 2004, 268). Governance both described and helped effect 'the restructuring of the relationship between the political and economic spheres' in which both the nature of the 'political' and its relationship to the 'economic' was redefined in ways that enhanced the latter at the expense of the former (Jessop 1997, 572). Though regarded by many scholars as a 'descriptive label' (e.g. Richards and Smith 2002, 2 ), 'governance' inscribed prescriptive imperatives onto the cluster of meanings attributed to it that helped shape understandings of both the theory and practice of governing. While this was similar to the impact of NPM, 'governance' more explicitly enabled political problems to be redefined as technical issues relating to administration and management. That is to say that political rule by governments and their relevant state apparatuses, when understood in terms of a governance lens, were merely a matter of economic management. In itself this gave governance great conceptual appeal.

This appeal was further enhanced by the fact that NPM could be recalibrated in terms of the emerging language of governance. Some of NPM's key features such as marketisation and an emphasis on the state steering rather than rowing were easily accommodated within the newly emerging governance discourses. But whereas NPM emphasised that state entities should reinvent or re-engineer themselves by adopting private sector practices, within the emerging governance literature the emphasis was on 'partnerships between governmental, para-governmental and nongovernmental organizations in which the state apparatus is often only first among equals' (Jessop 1997, 574-575). The state was to be less a central sponsor of government activities and more a facilitating partner. There is some resonance here with the governmentality approach in terms of decentring of the state. However, the key difference is that governmentality displaces the state rather than subordinates it, whereas governance (and to a lesser extent NPM) makes a virtue of the reconfigurations of publicprivate partnerships while simultaneously asserting the overall political authority of the state.

The nature of these public-private partnerships is not simply a matter of mutual convenience, because it also involves significant organisational change within the administrative apparatuses of the modern state. The NPM impetus to redesign organisational structures of state institutions, in particular enhancing the management authority of senior public sector executives, found a ready resonance within the rising governance discourses. These too created new and consolidated existing opportunities 
for non-state actors to join with state officials to become integral parts of state decision-making and policymaking processes. Private interests were then enabled to participate as legitimate insiders within the state's policymaking apparatuses. In that context, 'governance', both as concept and practice, is more than just 'the manner in which power is exercised in the management of a country's economic and social resources for development' (World Bank 1992, 1). It designates a form of political authority that is exercised through various administrative apparatuses and decision-making processes that are shared with private sector actors, in effect transforming political processes. This has implications for the forms of political authority that might be possible within those reconfigurations as these arrangements have the potential to transform political institutions in unanticipated and perhaps unwanted ways, in particular where the sovereign political authority of the elected government might be concerned (Jose 2011). Politicians may well see themselves as setting policy agendas, objectives and performance measures, but the basis for their decisions and pronouncements still depend on advice from others (e.g. party apparatchiks, personal assistants, media advisers, so-called independent consultants and so on), all of whom think, write and advise within various contexts in which neoliberal ideas are the norm.

Furthermore, the decision-making processes within public sector organisations become subject to two competing but not necessarily incompatible tensions. On the one hand, decision-making processes become subordinated to the logic of the market rather than to a logic authorised by democratic political processes in which policy decisions are entrusted to elected politicians. On the other hand, the decision-making processes become subject to a different political logic driven by elected politicians' attempts to seek 'partisan advantage over their competitors', an outcome described by Aucoin $(2012,178)$ as 'new political governance'. Space precludes exploring this aspect further. Suffice it to say that it underscores one of the problem areas of the governance paradigm (Peters 2003; Stoker 1998, 2019), namely the politicisation of the public sector and the possible concomitant decline of trust in government generally. The very measures aimed at improving the state's flexibility, responsiveness, and efficiency present the potential to weaken the state's legitimacy as they form part of a mindset as to how those charged with acting in the public interest, in particular politicians and perhaps to a lesser extent senior bureaucrats, understand and discharge their roles and responsibilities. 


\section{Conclusion}

My discussion began from a suspicion that the place of the state within Wanna's scholarship mirrored a parallel decline in its prominence within public policy and public administration scholarship. Scholars turned to other conceptual means of analysis such as 'political regime', 'governmentality', 'NPM', and 'governance'. Considered individually, each of these had particular appeal. But considered in the context of a trajectory of public policy and public administration scholarship over the past six or seven decades, a less appealing picture emerges. Two concepts, 'political regime' and 'governmentality', could be described as heuristic in their deployment in theorising the operations of the state (though it could also be argued that the latter has its own paradigm of sorts). The other two concepts, 'NPM' and 'governance', were more than simply heuristic terms. Not only did they provide a means to explain what was happening within the state's organisational and political architecture, they assisted in shaping and providing justifications for those reconfigurations to become practices of governing.

As products of the post-Keynesian zeitgeist, both NPM and governance enjoyed what might be considered a form of conceptual hegemony, to the extent that they formed paradigms in the Kuhnian sense (Kuhn 1970, 35-42). That is, each concept provided 'an organizing ... framework for understanding changes in governing', as Stoker $(1998,18)$ asserted in the case of governance, that involved a fusion of 'intellectual and ideological dimensions', as Aucoin $(1990,116)$ noted in relation to NPM. Thus, both concepts set the boundaries defining the puzzles and activities that could be explored, the legitimacy of the questions that might be asked and the answers that might be permitted. In such a context concerns about theorising the state as a focus for research receded as the seemingly more practical concerns about policy and administration appeared more accessible.

This did not mean that all such consideration of the state disappeared, as I have already noted above. But it did mean that the state became more of a taken-for-granted term, deployed by scholars in an unproblematic way, as a background condition for the analysis of other phenomena within frameworks shaped by terms like 'NPM' or 'governance'. Hence the diminishing importance of the state qua state within Wanna's research trajectory was not something peculiar to his individual choices about the 
particular objects of his research. It was part of a wider (inter-)disciplinary phenomenon in which ideas about the nature and practices of governing came to be rethought and reconfigured.

\section{References}

Allen, P. and J. Wanna. 2016. 'Developing leadership and building executive capacity in the Australian public services for better governance'. In A. Podger and J. Wanna (eds) Sharpening the Sword of State: Building Executive Capacities in the Public Services of the Asia-Pacific. Canberra: ANU Press. doi.org/10.22459/ SSS.11.2016.02.

Almond, G. 1988. 'The return to the state (and critiques)'. American Political Science Review 82(3): 853-874. doi.org/10.2307/1962495.

Andersen, D., J. Møller, L. L. Rørbæk and S.-E. Skaaning. 2014. 'State capacity and political regime stability'. Democratization 21(7): 1305-1325. doi.org/ 10.1080/13510347.2014.960204.

Aucoin, P. 1990. 'Administrative reform in public management: Paradigms, principles, paradoxes and pendulums'. Governance: An International Journal of Policy, Administration, and Institutions 3(2): 115-137. doi.org/10.1111/ j.1468-0491.1990.tb00111.x.

Aucoin, P. 2012. 'New political governance in Westminster systems: Impartial public administration and management performance at risk'. Governance: An International Journal of Policy, Administration, and Institutions 25(2): 177199. doi.org/10.1111/j.1468-0491.2012.01569.x.

Bale, M. and T. Dale. 1998. 'Public sector reform in New Zealand and its relevance to developing countries'. The World Bank Research Observer 13(1): 103-121. doi.org/10.1093/wbro/13.1.103.

Barbalet, J.M. 1974. 'Political science, the state and Marx'. Politics (now Australian Journal of Political Science) 9(1): 69-73. doi.org/10.1080/003232674084 01441.

Barraclough, H. 1940. 'Engineering the state'. Australian Journal of Public Administration 2(3): 173-195. doi.org/10.1111/j.1467-8500.1940.tb01932.x.

Barzelay, M. 2005. 'Origins of the new public management: An international view from public administration/political science'. In K. McLaughlin, S. P. Osborne and E. Ferlie (eds) New Public Management: Current Trends and Prospects. London: Routledge. 
Bell, S. and A. Hindmoor. 2009. Rethinking Governance: The Centrality of the State in Modern Society. Cambridge: Cambridge University Press. doi.org/10.1017/ CBO9780511814617.

Bevir, M. 2010. Democratic Governance. Princeton: Princeton University Press. doi.org/10.1515/9781400836857.

Bevir, M. and R. A. W. Rhodes. 2003. Interpreting British Governance. London: Routledge.

Bevir, M. and R. A. W. Rhodes. 2010. The State as Cultural Practice. Oxford: Oxford University Press. doi.org/10.1093/acprof:oso/9780199580750.001.0001.

Block, F. and M. Somers. 2016. The Power of Fundamentalism: Karl Polanyis Critique. Cambridge, MA: Harvard University Press.

Blyth, M. 2002. Great Transformations: Economic Ideas and Institutional Change in the Twentieth Century. Cambridge: Cambridge University Press. doi.org/ 10.1017/CBO9781139087230.

Buchanan, J. M. and R. E. Wagner. 1977. Democracy in Deficit: The Political Legacy of Lord Keynes. New York: Academic Press.

Catley, R. and B. McFarlane. 1981. Australian Capitalism in Boom and Depression. Chippendale: Alternative Publishing Cooperative.

Christensen, T. and P. Laegreid. 2002. 'New public management: Puzzles of democracy and the influence of citizens'. Journal of Political Philosophy 10(3): 267-295. doi.org/10.1111/1467-9760.00153.

Clarke, T. and S. R. Clegg. 1999. 'Changing paradigms in public service management'. Administrative Theory \& Praxis 21(4): 485-459. doi.org/ 10.1080/10841806.1999.11643406.

Colebatch, H. K. 2002. Policy. Revised edition. Buckingham: Open University Press.

Connell, R. W. 1977. Ruling Class, Ruling Culture: Studies of Conflict, Power and Hegemony in Australian Life. Cambridge: Cambridge University Press. doi.org/ 10.1017/CBO9781139085076.

Crouch, C. 2004. Post-Democracy. Cambridge: Polity Press.

Crough, G. and E. L. Wheelwright. 1982. Australia: A Client State. Ringwood: Penguin Books. 
Crozier, M., S. Huntington and J. Watanuki. 1975. The Crisis of Democracy: Report on the Governability of Democracies to the Trilateral Commission. Triangle Paper No. 8. New York: New York University Press.

Dahl, R. 1982. Dilemmas of Pluralist Democracy. New Haven: Yale University Press.

Dahl, R. 1985. A Preface to Economic Democracy. Cambridge: Polity Press. doi.org/ $10.1525 / 9780520341166$.

Davis, G., J. Wanna, J. Warhurst and P. Weller. (1988) 1993. Public Policy in Australia. Second edition. Sydney: Allen \& Unwin.

Dean, M. and B. Hindess (eds). 1998. Governing Australia: Studies in Contemporary Rationalities of Government. Cambridge: Cambridge University Press.

Dean, M. and K. Villadsen. 2016. State Phobia and Civil Society: The Political Legacy of Michel Foucault. Stanford: Stanford University Press.

Dent, M., J. Chandler and J. Barry (eds). 2004. Questioning the New Public Management. Aldershot: Ashgate.

Diefenbach, T. 2009. 'New public management in public sector organizations: The dark sides of managerialistic "enlightenment". Public Administration 87(4): 892-909. doi.org/10.1111/j.1467-9299.2009.01766.x.

Drucker, P. 1968. The Age of Discontinuity: Guidelines to Our Changing Society. New York: Harper and Row.

Dunleavy, P. and C. Hood. 1994. 'From old public administration to new public management'. Public Money and Management 14(3): 9-16. doi.org/10.1080/ 09540969409387823.

Dunleavy, P., H. Margetts, S. Bastow and J. Tinkler. 2006. 'New public management is dead-Long live digital-era governance'. Journal of Public Administration Research and Theory 16(3): 467-494. doi.org/10.1093/jopart/ mui057.

Easton, D. 1981. 'The political system besieged by the state'. Political Theory 9: 303-325. doi.org/10.1177/009059178100900303.

Encel, S. 1960. 'The concept of the state in Australian politics'. Australian Journal of Politics and History 6(1): 62-76. doi.org/10.1111/j.1467-8497.1960. tb00782.x.

Evans, P., D. Rueschemeyer and T. Skocpol (eds). 1985. Bringing the State Back In. Cambridge: Cambridge University Press. doi.org/10.1017/CBO978051162 8283. 
Firestone, S. 1971. Dialectic of Sex: The Case for Feminist Revolution. London: Jonathan Cape.

Foucault, M. 1979. 'Governmentality'. Ideology \& Consciousness 6: 5-21.

Foucault, M. 1981. 'Omnes et singulatum: Towards a criticism of "political reason"'. In S. M. McMurrin (ed.) The Tanner Lectures on Human Values, II. Salt Lake City: University of Utah Press.

Foucault, M. 1982. 'The subject and power'. Critical Inquiry 8(4): 777-795. www.jstor.org/stable/1343197.

Foucault, M. 1984. The History of Sexuality Volume 1: An Introduction. Translated by R. Hurley. Harmondsworth: Penguin Books.

Foucault, M. 1997. 'What our present is'. In S. Lotringer and L. Hocbroth (eds) The Politics of Truth. New York: Semiotext(e).

Foucault, M. 2000. 'The ethics of the concern for the self as a practice of freedom'. In M. Foucault, Ethics: Essential Works of Foucault 1954-1984. Volume 1 of 3 volumes. Edited by P. Rabinow. London: Penguin Books.

Foucault, M. 2004. Society Must Be Defended? Lectures at the College de France, 1975-1976. Translated by D. Macey. Harmondsworth: Penguin Books.

Foucault, M. 2007. Security, Territory, Population: Lectures at the Collège de France 1977-1978. Translated by G. Burchell. Basingstoke: Palgrave Macmillan.

Foucault, M. 2008. The Birth of Biopolitics: Lectures at the Collège de France 19781979. Translated by G. Burchell. Basingstoke: Palgrave Macmillan.

Frankel, B. 1979. 'On the state of the state: Marxist theories of the state after Leninism'. Theory and Society 7(1/2): 199-242. doi.org/10.1007/BF00158682.

Frankel, B. 1983. Beyond the State? Dominant Theories and Socialist Strategies. London: Macmillan Press.

Franzway, S., D. Court and R. W. Connell. 1989. Staking a Claim: Feminism, Bureaucracy and the State. Sydney: Allen \& Unwin.

Fukuyama, F. 1989. 'The end of history?' The National Interest 16(Summer): 3-18.

Galligan, B. 1984. 'The state in Australian political thought'. Politics (now Australian Journal of Political Science) 19(2): 82-92. doi.org/10.1080/0032326840840 1923.

Game, A. and R. Pringle. 1983. Gender at Work. Sydney: Allen \& Unwin. 
Gornick, V. and B. K. Moran (eds). 1971. Woman in Sexist Society: Studies in Power and Powerlessness. New York: Basic Books.

Hancock, K. 1930. Australia. London: Benn.

Harvey, D. 2007. A Brief History of Neoliberalism. Oxford: Oxford University Press.

Head, B. 1984. 'Recent theories of the state'. Politics (now Australian Journal of Political Science) 19(1): 36-45. doi.org/10.1080/00323268408401906.

Hill, M. and P. Hupe. 2002. Implementing Public Policy: Governance in Theory and Practice. London: Sage Publications.

Holloway, J. and S. Picciotto (eds). 1978. State and Capital: A Marxist Debate. London: Edward Arnold.

Hood, C. 1991. 'A public management for all seasons?' Public Administration 69(1): 3-19. doi.org/10.1111/j.1467-9299.1991.tb00779.x.

Jessop, B. 1982. The Capitalist State: Marxist Theories and Methods. Oxford: Martin Robertson \& Co.

Jessop, B. 1997. 'Capitalism and its future: Remarks on regulation, government and governance'. Review of International Political Economy 4(3): 561-581. doi.org/10.1080/096922997347751.

Jessop, B. 2003. 'Governance, governance failure and metagovernance'. Paper presented to the Politics, Governance and Innovation for Rural Area International Seminar, Università della Calabria, Arcavacata di Rende, 21-23 November. Available at: www.researchgate.net/publication/228960146_ Governance_Governance_Failure_and_Meta-Governance.

Jessop, B. 2004. 'Multi-level governance and multi-level meta-governance'. In I. Bache and M. Flinders (eds) Multi-level Governance. Oxford: Oxford University Press.

Jessop, B. 2015. The State: Past, Present and Future. Cambridge: Polity Press.

Jones, D. S. 2014. Masters of the Universe: Hayek, Friedman, and the Birth of Neoliberal Politics. Princeton: Princeton University Press.

Jose, J. 2003. 'Revisioning the logic of industrialisation: Contesting the common sense of our time'. In E. Carlson (ed.) The Full Employment Imperative. Callaghan, NSW: University of Newcastle, Centre of Full Employment and Equity. 
Jose, J. 2007. 'Reframing the "governance" story'. Australian Journal of Political Science 42(3): 455-470. doi.org/10.1080/10361140701513588.

Jose, J. 2010. 'A (con)fusion of discourses? Against the governancing of Foucault'. Social Identities 16(5): 689-703. doi.org/10.1080/13504630.2010.509574.

Jose, J. 2011. 'Responding to terrorism in the era of the governance state'. In B. B. Hawks and L. Baruh (eds) If It Was Not for Terrorism: Crisis, Compromise, and Elite Discourse in the Age of War on Terror. Newcastle, UK: Cambridge Scholars Press.

Keating, M. 2004. Who Rules? How Government Retains Control of a Privatised Economy. Sydney: Federation Press.

King, A. 1975. 'Overload: Problems of governing in the 1970s'. Political Studies 23: 284-296. doi.org/10.1111/j.1467-9248.1975.tb00068.x.

King, A. (ed.). 1978. The New American Political System. Washington, DC: American Enterprise Institute.

Kirkpatrick, I., S. Ackroyd and R. Walker (eds). 2005. The New Managerialism and Public Service Professions. New York: Palgrave Macmillan. doi.org/10.1057/ 9780230503595.

Kooiman, J. (ed.). 1993. Modern Governance: New Government-Society Relations. London: Sage.

Kuhn, T. S. 1970. The Structure of Scientific Revolutions. Second edition, enlarged. Chicago: University of Chicago Press.

Lapsley, I. 2009. 'New public management: The cruellest invention of the human spirit?' Abacus: A Journal of Accounting, Finance and Business Studies. 45(1): 1-21. doi.org/10.1111/j.1467-6281.2009.00275.x.

Lindblom, C. 1977. Politics and Markets. New York: Basic Books.

Lister, M. and D. Marsh. 2006. 'Conclusion'. In C. Hay, M. Lister and D. Marsh (eds) The State: Theories and Issues. Basingstoke: Palgrave Macmillan.

Lynn Jr, L. E. 2006. Public Management: Old and New. New York: Routledge. doi.org/10.4324/9780203964774.

Lynn Jr, L. E., C. J. Heinrich and C. J. Hill. 2000. 'Studying governance and public management: Challenges and prospects'. Journal of Public Administration Research and Theory 10(2): 233-261. doi.org/10.1093/oxfordjournals.jpart. a024269. 
MacKinnon, C. 1982. 'Feminism, Marxism, method, and the state: An agenda for theory'. Signs: Journal of Women in Culture and Society 7(3): 515-524. doi.org/ 10.1086/493898.

MacKinnon, C. 1983. 'Feminism, Marxism, method, and the state: Toward feminist jurisprudence'. Signs: Journal of Women in Culture and Society 8(4): 635-658. doi.org/10.1086/494000.

MacKinnon, C. 1989. Towards a Feminist Theory of the State. Cambridge, MA: Harvard University Press.

Mayer, H. 1952. 'Notes on Marxism and the state'. Australian Journal of Public Administration 11(3): 129-142. doi.org/10.1111/j.1467-8500.1952. tb01592.x.

McEachern, D. 1990. The Expanding State: Class and Economy Since 1945. London: Harvester Wheatsheaf Press.

McFarland, A. 2007. Neopluralism. Annual Review of Political Science 10: 45-66. doi.org/10.1146/annurev.polisci.10.072005.152119.

McGregor Jr, E. B. 1993. 'Toward a theory of public management success'. In B. Bozeman (ed.) Public Management: The State of the Art. San Francisco: Jossey-Bass.

McLaughlin, K. and S. P. Osborne. 2005. 'Current trends and future prospects of public management: A guide’. In K. McLaughlin, S. P. Osborne and E. Ferlie (eds) New Public Management: Current Trends and Future Prospects. London: Routledge. doi.org/10.4324/9780203996362.

McLaughlin, K., S. P. Osborne and E. Ferlie (eds) 2005. New Public Management: Current Trends and Future Prospects. London: Routledge. doi.org/10.4324/ 9780203996362.

Miliband, R. 1969. The State in Capitalist Society. New York: Basic Books.

Millett, K. 1971. Sexual Politics. London: Granada Publishing.

Mintrom, M. and J. Wanna. 2006. 'Innovative state strategies in the Antipodes: Enhancing the ability of governments to govern in the global context'. Australian Journal of Political Science 41(2): 161-176. doi.org/10.1080/ 10361140600672410.

Morgan, R. (ed.). 1970. Sisterhood is Powerful: An. Anthology of Writings from the Women's Liberation Movement. New York: Vintage Books.

Nordlinger, E. 1981. On the Autonomy of the Democratic State. Cambridge, MA: Harvard University Press. 
O'Connor, J. 1973. The Fiscal Crisis of the State. New York: St Martin's Press.

O'Donnell, C. 1984. The Basis of the Bargain: Gender, Schooling and Jobs. Sydney: Allen \& Unwin.

Offe, C. 2009. 'Governance an “empty signifier”?' Constellations 16(4): 550-562. doi.org/10.1111/j.1467-8675.2009.00570.x.

Offe, C. and V. Ronge. 1975. 'Theses on the theory of the state'. New German Critique 6: 137-147. doi.org/10.2307/487658.

Osborne, D. and T. Gaebler. 1992. Re-Inventing Government: How the Entrepreneurial Spirit is Transforming the Public Sector. New York: Harper.

Pateman, C. 1983. 'Feminist critiques of the public/private dichotomy'. In S. I. Benn and G. F. Gaus (eds) Public and Private in Social Life. New York: St Martin's Press.

Pempel, T. J. 1997. 'Regime shift: Japanese politics in a changing world economy'. Journal of Japanese Studies 23(2): 333-361. doi.org/10.2307/133160.

Peters, B. G. 2003. 'The changing nature of public administration: From easy answers to hard questions'. Viešoji Politika ir Administravimas 5: 7-20.

Pierre, J. and B. G. Peters. 2000. Governance, Politics and the State. London: Macmillan.

Podger, A. and J. Wanna (eds). 2016. Sharpening the Sword of State: Building Executive Capacities in the Public Services of the Asia-Pacific. Canberra: ANU Press. doi.org/10.22459/SSS.11.2016.

Pollitt, C. 1990. Managerialism and the Public Services: The Anglo-Saxon Experience. Oxford: Basil Blackwell.

Pollitt, C., S. van Thiel and V. Homburg (eds). 2007. New Public Management in Europe: Adaptation and Alternatives. London: Palgrave Macmillan. doi.org/ $10.1057 / 9780230625365$.

Poulantzas, N. 1978. State, Power, and Classes. Translated by P. Camiller. London: NLB.

Poulantzas, N. and R. Miliband. 1972. 'The problem of the capitalist state'. In R. Blackburn (ed.) Ideology in Social Science: Readings in Critical Social Theory. London: Fontana/Collins.

Prozorov, S. 2004. 'Three theses on "governance" and the political'. Journal of International Relations and Development 7(3): 267-293. doi.org/10.1057/ palgrave.jird.1800023. 
Przeworski, A. and F. Limongi. 1993. 'Political regimes and economic growth'. Journal of Economic Perspectives 7(3): 51-69. doi.org/10.1257/jep.7.3.51.

Pusey, M. 1991. Economic Rationalism in Canberra: A Nation-Building State Changes its Mind. Melbourne: Cambridge University Press.

Rhodes, R. A. W. 1997. Understanding Governance: Policy Networks, Governance, Reflexivity and Accountability. Buckingham: Open University Press.

Richards, D. and M. J. Smith. 2002. Governance and Public Policy in the United Kingdom. Oxford: Oxford University Press.

Roberts, A. 2010. The Logic of Discipline: Global Capitalism and the Architecture of Government. Oxford: Oxford University Press.

Rose, R. 1975. 'Overloaded government: The problem outlined'. European Studies Newsletter 5: 13-18.

Rose, R. 1999. Powers of Freedom: Reframing Political Thought. Cambridge: Cambridge University Press. doi.org/10.1017/CBO9780511488856.

Sawer, M. 1983. 'From the ethical state to the minimal state: State ideology in Australia'. Politics (now Australian Journal of Political Science) 18(1): 26-35. doi.org/10.1080/00323268308401870.

Sawer, M. 1990. Sisters in Suits: Women and Public Policy in Australia. Sydney: Allen \& Unwin.

Singer, B. C. J. and L. Weir. 2006. 'Politics and sovereign power: Considerations on Foucault'. European Journal of Social Theory 9(4): 443-465. doi.org/ $10.1177 / 1368431006073013$.

Skidelsky, R. 2019. Money and Government: The Challenge to Mainstream Economics. Harmondsworth: Penguin Books.

Skocpol, T. 1979. States and Social Revolutions: A Comparative Analysis of France, Russia, and China. Cambridge: Cambridge University Press. doi.org/10.1017/ CBO9780511815805.

Sokhi-Bulley, B. 2011. 'Government(ality) by experts: Human rights as governance'. Law Critique 22: 251-271. doi.org/10.1007/s10978-011-9091-4.

Stoker, G. 1998. 'Governance as theory: Five propositions'. International Social Science Journal 50(155): 19-28. doi.org/10.1111/1468-2451.00106.

Stoker, G. 2019. 'Can the governance paradigm survive the rise of populism?' Policy \& Politics 47(1): 3-18. doi.org/10.1332/030557318X15333033030897. 
Summers, A. 1975. Damned Whores and God's Police: The Colonization of Women in Australia. Ringwood: Penguin Books.

Torres, L. 2004. 'Trajectories in public administration reforms in European continental countries'. Australian Journal of Public Administration 63(3): 99112. doi.org/10.1111/j.1467-8500.2004.00394.x.

Wamsley, G. L. 1990. 'The agency perspective: Public administrators as agential leader'. In G. L. Wamsley, R. N. Bacher, C. T. Goodsell and P. S. Kronenberg (eds) Refounding Public Administration. Newbury Park: Sage.

Wanna, J. 1981. Defence Not Defiance: The Development of Organised Labour in South Australia. Adelaide: CAE Government Printer.

Wanna, J. 1986. 'The state and industrial relations in South Australia'. In K. Sheridan (ed.) The State as Developer: Public Enterprise in South Australia. Adelaide: Royal Australian Institute of Public Administration in association with Wakefield Press.

Wanna, J. 1994. 'Can the state "manage" the macroeconomy?' In S. Bell and B. Head (eds) State, Economy and Public Policy. Melbourne: Oxford University Press.

Watson, S. (ed.). 1990. Playing the State: Australian Feminist Interventions. Sydney: Allen \& Unwin.

Weiss, L. 2005. 'The state-augmenting effects of globalisation'. New Political Economy 10(3): 345-353. doi.org/10.1080/13563460500204233.

Wheelwright, E. L. and K. Buckley (eds). 1975-1983. Essays in the Political Economy of Australian Capitalism. 5 volumes. Sydney: ANZ Book Publishing.

Wilenski, P. 1988. 'Social change as a source of competing values in public administration'. Australian Journal of Public Administration 47(3): 213-222. doi.org/10.1111/j.1467-8500.1988.tb01062.x.

World Bank. 1989. Sub-Saharan Africa: from Crisis to Sustainable Growth. Washington DC: World Bank Publications.

World Bank. 1992. Governance and Development. Washington DC: World Bank Publications.

Yaffe, D.S. 1973. 'The Marxian theory of crisis, capital and the state'. Economy and Society 2(2): 186-232. doi.org/10.1080/03085147300000009. 
This text is taken from Politics, Policy and Public Administration in Theory and Practice: Essays in Honour of Professor John Wanna, edited by Andrew Podger, Michael de Percy and Sam Vincent, published 2021 by ANU Press, The Australian National University, Canberra, Australia.

doi.org/10.22459/PPPATP.2021.12 